Zabytkoznawstwo i Konserwatorstwo XLIII, Toruń 2012

Małgorzata Baka-Theis*, Sławomir Majoch**

* Uniwersytet Mikołaja Kopernika w Toruniu, doktorantka

** Muzeum Uniwersyteckie w Toruniu

\title{
Afrykanika z kolekcji Aleksandra Wernera w zbiorach Muzeum Uniwersyteckiego w Toruniu
}

\section{Aleksandrowi Wernerowi}

pro memoriam

$\mathrm{M}$

uzeum Uniwersyteckie w Toruniu jest instytucja młoda, utworzona w 2005 r., na Uniwersytecie Mikołaja Kopernika w Toruniu, będacym spadkobierca tradycji przedwojennego Uniwersytetu Stefana Batorego w Wilnie, na którym funkcjonowały trzy muzea: Przyrodnicze ${ }^{1}$, Etnograficzne ${ }^{2}$ i Archeologiczne ${ }^{3}$. W ostatnim z wymienionych prezentowane były m.in. zabytki starożytnego Egiptu ${ }^{4}$. Pomimo zaledwie pięcioletniego stażu, w toruńskim muzeum udało się zgromadzić kilka tysięcy obiektów pocho-

1 J. Prüffer, Muzeum Prayrodnicze Uniwersytetu Stefana Batorego w Wilnie, Wilno 1932 [nadbitka z: „Alma Mater Vilnensis” 1932, nr 10].

2 M. Znamierowska-Prüfferowa, Muzeum Etnograficzne Uniwersytetu Stefana Batorego w Wilnie i jego prayssłtość, Lwów-Wilno 1932 [nadbitka z: „Kwartalnik Etnograficzny Lud”, 1932, Serja 2, t. 11]; W. Olszewski, Zatożenia Muzeum Etnograficznego pray Uniwersytecie Stefana Batorego i ich rozwiniecie w pracach Marii Znamierowskiej-Prüfferowej, [w:] Prayszztość etnologii polskiej w jej teraźniejszości, red. Z. Jasiewicz, T. Karwicka, Poznań 2001, s. 79-84.

3 W. Hołubowicz, Piéć lat pracy terenowej Muzeum Archeologicrnego Uniwversytetu Stefana Batorego w Wilnie (1933-1937), „Rocznik Archeologiczny” 1937, t. 1, s. 83-90.

${ }^{4}$ W. Hołubowicz, Mumje egipskie w Wilnie, Wilno 1933. 
dzących ze wszystkich zamieszkanych kontynentów 5 . Wśród darów znalazła się spuścizna artystyczna po mieszkającym w Londynie Aleksandrze Wernerze, obejmująca blisko osiemset jego prac oraz kolekcja licząca 172 obiekty ${ }^{6}$.

Aleksander Werner (1920-2011) - rzeźbiarz, malarz, grafik i pedagog, urodzony w rodzinie o artystycznych korzeniach sięgajacych XVII wieku', związany był w młodości z Toruniem, Legionowem i Lwowem. Po wybuchu II wojny światowej został deportowany w głąb Związku Radzieckiego i osadzony w obozie pracy. W 1941 roku, po umowie Sikorski-Majski, dostał się do Polskiej Armii na Bliskim Wschodzie, pod dowództwem generała Władysława Andersa. Wraz z II Korpusem przebył kraje Bliskiego Wschodu i Egipt, skąd następnie trafił do Włoch, gdzie walczył pod Monte Cassino. W 1945 roku podjął studia malarskie w utworzonej przez profesora Mariana Szyszko-Bohusza, Sekcji Artystów i Studentów Sztuk Pięknych Żołnierzy II Korpusu Kompanii Kresowej na Akademii Sztuk Pięknych w Rzymie. W 1946 roku wyjechał do Wielkiej Brytanii, w której pozostał aż do śmierci. Studiował grafikę w Sir John Cass' School of Art w Londynie, a następnie pracował w Camberwell School of Arts and Crafts. Był

5 W toruńskim Muzeum Uniwersyteckim przyjęto nowatorską na gruncie polskim koncepcję, wedle której jest jednostką jednorodną bez podziału na działy, z jednym inwentarzem stałym oraz inwentarzem depozytów. Pozwala to na szybkie wpisanie obiektów do ewidencji i łatwe zarządzanie zbiorami. Intensywny napływ obiektów powoduje, że nieliczna kadra merytoryczna nie jest w stanie na bieżąco opracowywać zbiorów. Stąd wybrane muzealia sa przekazywane do szczegółowych badań w ramach prac doktorskich i magisterskich. Podobnie było z kolekcją A. Wernera, której część opracowała Pani Małgorzata Baka-Theis. Por.: M. Baka-Theis, Afrykeańska kolekecja Aleksandra Wernera ₹. Muzeum Uniwersy-

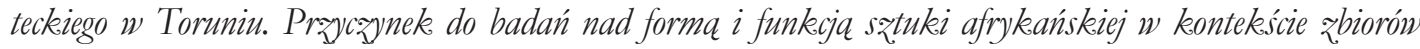
muzealnych, praca magisterska po kierunkiem prof. J. Malinowskiego, Instytut Zabytkoznawstwa i Konserwatorstwa, Wydział Sztuk Pięknych, Uniwersytet Mikołaja Kopernika w Toruniu, Toruń 2008.

"S. Majoch, Tryy tony dziet sqtuki, „Głos Uczelni” 2004, nr 9, s. 16; idem, Fascynujaca kolekcja. Dwaj oksfordzcy naukowcy w torunskim Muzeum Uniwersyteckim, „Głos Uczelni” 2005, nr 2, s. 25.

A.M. Borkowski, Zastony i czeluście Aleksandra Wernera, „Tydzień Polski”, 25 X 1995, nr 42, s. 12 [przedruk w: Sztuka polska w Wielkiej Brytanii w latach 1940-2000. Antologia, wybrał, przygotował do druku i wstępem opatrzył M. A. Supruniuk, Toruń 2006, s. 314-316]; M.B. Topolska, Werner Aleksander, [w:] Encyklopedia polskiej emigracii i Polonii, red. K. Dopierała, t. 5: S-Ż, Toruń 2005, s. 232-233; J. W. Sienkiewicz, Artysta piekna i nie tylko w sæzkło zakletego. Aleksander Werner (1920-2011), „Archiwum Emigracji” 2011, z. 1-2, s. 394-395. 
członkiem londyńskiej Grupy 49, skupiającej Polaków wywodzących się ze szkoły malarskiej Szyszko-Bohusza. Miał kilka wystaw indywidualnych m.in. w londyńskim Victoria and Albert Museum oraz w Bibliotece Kongresu w Waszyngtonie. Oprócz grafiki, malarstwa i rzeźby, zajmował się projektowaniem szat graficznych książek ${ }^{8}$, aranżacja wnętrz (m.in. kawiarni „Kon-Tiki”) oraz reklamą (m.in. plakaty Marocco i Africa dla Air Fran$\left(e^{9}\right)$. W twórczości Wernera, cały czas niedostatecznie zbadanej ${ }^{10}$, inspiracje sztuką afrykańską są zauważalne i znaczące, zarówno w tematyce prac, jak i ich formie artystycznej. Jest to jednak temat wymagajacy osobnego opracowania.

Werner był stałym bywalcem British Museum, interesującym się sztuką pozaeuropejska, co zapewne miało związek z gromadzona przez niego kolekcja. Wielokrotnie podróżował; w latach 60. odwiedził Indie, Meksyk i Maroko. Intensywną pracę przerwał w 1996 r. udar, który spowodował częściowy paraliż i utrudniony kontakt z otoczeniem. Ostatnie lata życia spędził w szpitalu.

W kolekcji przekazanej przez Wernera, a obecnie w części prezentowanej na stałej wystawie Skarby Uniwersytetu Mikołaja Kopernika w Toruniu, są zarówno antyczne naczynia cypryjskie z VII/VI w. p.n.e., szkła i ceramika syro-palestyńska z I-III w n.e. ${ }^{11}$, jak i dzieła z Indii, Tajlandii, Ameryki Południowej oraz europejska sztuka ludowa. Afrykanika, w kontekście całości zbioru, stanowią niewielki zespół. Składają się na nie: figurka z kości, przedstawiająca urzędnika z Królestwa Beninu (obecnie Nigeria) (il. 1),

8 M.in.: Seaforth Mackenzie, Dead men rising (1951); Robert Ardrey, African Genesis. A personal Investigation into the Animal Origins and nature of Man (1961).

9 Wykorzystał m.in. wizerunek figury relikwiarzowej Mbulu Ngulu plemienia Bakota (Kota) z Gabonu.

${ }^{10}$ Jedyna praca monograficzna o artyście, w najmniejszym stopniu nie wyczerpuje analizy jego twórczości. Por.: D. M. Świstun, Aleksander Werner - artysta i jego džieło (ur. 1920), praca magisterska z historii sztuki napisana w Katedrze Historii Sztuki i Kultur, pod kierunkiem prof. dr hab. Krzysztofa Pomiana, Wydział Nauk Historycznych, UMK w Toruniu, Toruń 2004.

11 I. Głuszek, E. Kozłowska, S. Majoch, M. Olszta-Bloch, Ancient pottery and glass from the collection of the University Museum in Torun | Ceramika i sqk kto antyczne w zbiorach Muzeum Uniwersyteckiego $w$ Toruniu, (catalogues of the collection from University Museum in Torun | Poland | Katalogi zbiorón Muzeum Uniwersyteckiego w Toruniu, vol. 2, Torun 2013. 
rzeźba ibeji ludu Joruba z Nigerii (il. 2), dwie lalki akuaba ludu Aszanti z Ghany (il. 3-4), maska kapeluszowa chiwara, ludu Bamana z Mali (il. 5), miniaturowa maska stylistycznie zbliżona do rzeźby ludu Baule z Wybrzeża Kości Słoniowej (il. 6) i podgłówek ludu Kambatta z Etiopii (il. 7). Kolekcję rzeźbiarską uzupełniają obiekty codziennego użytku: dwie dwuczęściowe malowane tykwy ludu Turkana z Kenii, i pięć naczyń ceramicznych powstałych w północnej części Afryki.

Nie znamy pochodzenia zbioru, choć dobry stan zachowania, jak i profesjonalna podstawa, do której przytwierdzono rzeźbę z kości słoniowej, moga sugerować - w przypadku rzeźb - zakupy antykwaryczne. Londyn po drugiej wojnie światowej należał do najważniejszych ośrodków antykwarycznych i centrów obrotu dziełami pochodzącymi z Afryki. Wśród antykwariatów oferujących artefakty pozaeuropejskie, znalazła się Centaur Gallery, prowadzona przez Dinah i Jana Wieliczków ${ }^{12}$, w której można „było znaleźć wszystko; od obrazu (często dobrego) do maski murzyńskiej, o której właściciel dawał zawsze uczciwe informacje - czy jest prawdziwa, czy też podrobiona". ${ }^{13}$ Rzeźby afrykańskie gromadził także w Londynie Mateusz Grabowski, prowadzący Grabowski Gallery, w której Werner wielokrotnie wystawiał swoje prace. ${ }^{14}$

Naczynia został zakupione podczas podróży Wernera do Północnej Afryki. Geneza pozostałych obiektów może być oparta jedynie na analizie formy i porównaniach z analogicznymi pracami.

Najciekawszym obiektem kolekcji jest statuetka z kości słoniowej, przedstawiająca urzędnika (dworzanina), w stylu Królestwa Beninu (nr inw:: MUT 237/KW 2) il. 1. Mierząca nieco ponad $10 \mathrm{~cm}$ wys. figurka, wykonana została przy użyciu ostrych narzędzi, których ślad odnaleźć można na jej powierzchni i nie została ukończona.

Wiele artefaktów z Beninu trafilo do Europy za sprawą brytyjskiej aneksji królestwa w 1898 r., w czasie której ograbiono pałac władcy - oby, a także za pośrednictwem podróżników i marszandów, działających na po-

12 J. W. Sienkiewicz, Polskie galerie s₹tuki w Londynie w drugiej połowie XX wieku, LublinLondyn 2003, s. 185.

13 M. Bohusz-Szyszko, Wieliczko i jego Centaur Gallery, „Tydzień Polski” 1974, nr 37, s. 4.

14 J. W. Sienkiewicz, op. cit., fot. 142-143. 
czątku XX w. w Londynie i Paryżu. W dworskich warsztatach Królestwa Beninu - odlewników (Igun Eronmwon) i rzeźbiarzy w kości i drewnie (Igbesanmwan $)^{15}$ - wykonywano przedmioty rzemiosła artystycznego przeznaczone zarówno na użytek oby ${ }^{16}$, kapłanów kultu Ezomo i najwyżej stojących w hierarchii urzędników, a także m.in. solniczki i krucyfiksy na zamówienie dworów europejskich (już w czasach nowożytnych) ${ }^{17}$. Obecność Portugalczyków w Królestwie Beninu, od końca XV w. ${ }^{18}$, nadała nowe znaczenie temu cennemu materiałowi. Obcych kulturowo przybyszów postrzegano jako władców z krainy umarłych ${ }^{19}$, mających siłę pokonania życia i śmierci, a także odbierania życia innym, a ich wizerunki przeniknęły do ikonografii dworskiej sztuki Królestwa Beninu, już w XVI w. ${ }^{20}$. Istotnym atrybutem Portugalczyków był ich charakterystyczny strój ${ }^{21}$, którego reminiscencje odnaleźć można w przedstawieniach dworzan i wojowników ${ }^{22}$.

Postać, przedstawiona w rzeźbie toruńskiej, mieści się w obszarze typowego, konwencjonalnego portretu - najbardziej popularnej formy sztuki benińskiej, w której postać ludzką ukazywano schematycznie, ale naturalistycznie, pozbawiając cech indywidualnych, jednocześnie z przypisanymi jej atrybutami, zwykle w sile wieku, o młodzieńczej budowie ciała, z reguły w pozycji stojącej. Postaci władców, jak również dworzan, są jednolite i obrazują trwałość form stosowanych w rzeźbie. Wyidealizowane postaci męskie łączy kompozycja ukazująca władcę w pełni dostojeństwa, często w układzie hieratycznym ${ }^{23}$. O statusie społecznym postaci informowały elementy biżu-

15 D. Inneh, The Guilds Working for the Palace, [in:] Benin - Kings and Rituals. Court Arts from Nigeria, ed. B. Plankensteiner, Wien-Berlin-Paris-Chicago 2007, s. 107.

16 Było to związane z symboliką kości, kultem boga Olokuna (bóg oceanu i wód), oznaczająca siłę, męstwo i trwałość rządów (P. Ben-Amos, Men and Animals in Benin Art, "Man" 1976, Vol. 11, s. 247).

17 D. Inneh, op. cit., s. 107.

18 S.P. Blier, Imaging otherness in ivory: African portrayals of the Portuguese ca. 1492, "Art Bulletin" 1993, Vol. 75, No. 3, s. 375-396.

19 P. Ben-Amos, Men and Animals In Benin Art., op. cit.

20 Aspekt niewolnictwa i symboliki kości słoniowej omawia szczegółowo: S.P. Blier, op. cit., s. 375-396.

21 Rhingrave - bufoniaste, szerokie nogawki; korpus w ryngrafie; płaszcz.

22 S.P. Blier, op. cit., s. 376.

23 Obę, władcę Królestwa Beninu, ukazywano zawsze frontalnie. E. Pasztory, Hieratic Composition in west African Art, "Art Bulletin" 1970, Vol. 52, No. 3, s. 299-306. 
terii, ozdób, a także skaryfikacje. Charakterystyczne są tu proporcje ciała, w stosunku 1:3 (głowa, tułów, nogi), co wiązało się z metafizycznym pojmowaniem piękna ${ }^{24}$, gdzie najważniejszym elementem była uwydatniona głowa, uważana za siedzibę przeznaczenia, indywidualności i duszy ${ }^{25}$. Konwencje twarzowe, charakterystyczne dla Beninu, przez wieki pozostawały prawie niezmienione ${ }^{26}$. Artyści akcentowali wyidealizowany tors, poprzez jego uwydatnienie, a od XVI w. zaokraglono także partię brzucha ${ }^{27}$. Istotną cechą był strój, który był obrazem bogactwa i wysokiego stanu w hierarchii społecznej, jednocześnie stanowił też atrybut przedstawionej postaci ${ }^{28}$. Rzeźba benińska przez wieki trzymała się kanonicznych form, które zmieniały się jedynie w detalach ${ }^{29}$. Nie można jednoznacznie stwierdzić, jaką funkcję pełniła przedstawiająca dostojnika dworskiego rzeźba z kolekcji Aleksandra Wernera. Szczególnie zastanawiający jest fakt, iż nie została ona ukończona (brak uszu, stóp lub podstawy). Charakterystyczne są skaryfikacje na policzkach, które nie są typowe dla stojących najwyżej w hierarchii dworzan, przedstawianych w rzeźbie brązowej, a z którymi wiązać można jedynie skaryfikacje w partii torsu. Przeważnie, poza dwoma bocznymi, łukowatymi liniami, przebiegającymi od wysokości piersi do bioder, oba i jego asysta przedsta-

24 I. Okpewho, Principles of Traditional African Art, "The Journal of Aesthetics and Art Criticism" 1977, Vol. 35, No. 3, s. 303.

25 P. Ben-Amos, P. Girshick, The Symbolism of Ancestral Altar in Benin, [in:] Benin - Kings and Rituals. Court Arts from Nigeria, ed. B. Plankensteiner, Wien-Berlin-Paris-Chicago 2007, s. 153.

${ }^{26}$ Kształtowanie twarzy postaci pozostawało w zgodności ze sferą symboliczna, odgrywającą niezwykle istotną rolę w portrecie władców. Duże oczy, często podkreślane wałkowatymi powiekami, odnosiły się do rozumu i doświadczenia (P. Ben-Amos, P. Girshick, The Symbolism..., s. 153); uwydatnione nozdrza oznaczały siłę oraz męstwo; zamknięte, wyraźnie rozgraniczone wargi były symbolem stanowczości (K. Curnow, Prestige..., s. 78); wydatne policzki były natomiast cechą dobrego charakteru.

27 Duża masa ciała, czy wręcz otyłość, była cechą pożądaną i świadczyła o bogactwie i zdrowiu. K. Curnow, Prestige..., s. 80.

28 Ibidem. Tradycyjnie stroje nie zakrywały torsu, który w rzeźbie ukazywany był odsłonięty. Ich wymiary określano w jardach i były oznaką bogactwa, ponieważ materiały były głównie importami luksusowymi. Stojacy na szczycie drabiny społecznej oba mógł nosić pełne odzienie, wykonywane m.in. z koralowych paciorków.

29 W rzeźbie benińskiej zaobserwować można niewielki rozwój kształtowania się formy ramion, rak i klatki piersiowej, natomiast nogi przedstawiano krępe i walcowate. Postaci ukazywano głównie w pozycji stojącej, rzadziej w siedzącej (za wyjątkiem rzeźb wielofiguralnych), z rozstawionymi do zewnątrz stopami (wygięcie stóp cechuje większość sztuki afrykańskiej). 
wiana była także ze skaryfikacjami w postaci długiej prostej linii, biegnacej przez środek brzucha. Poza charakterystyczna dla portretów władców, znana jest także z królewskich rzeźb mosiężnych Beninu i Ife. $\mathrm{O}$ wysokim statusie społecznym przedstawionej postaci świadczy pas tkaniny, przewieszony przez ramiona i trzymany w dłoniach, przeznaczonej w kulturze Królestwa Beninu wyłącznie dla mężczyzn po inicjacji ${ }^{30}$, a także naszyjniki Odigba, ozdobna opaska wokół głowy i pasy korali na nieukończonych nogach.

$\mathrm{Na}$ podstawie analizy formalnej i porównawczej, założyć można, iż rzeźba powstała w XVIII w. Wskazuje na to sposób kształtowania partii włosów, charakterystyczny dla tego okresu, mający odniesienie także w rzeźbie brązowej ${ }^{31}$. Nie ulega watpliwości, iż cechy stylistyczne, formy, utrwalony kanon przedstawiania postaci, tak blisko związanych ze soba warsztatów, działających na jednym dworze, przenikały się, a zatem pewne cechy stylistyczne, mogły być stosowane w tym samym czasie, zarówno w pełnoplastycznych rzeźbach mosiężnych, jak i drobnej plastyce z kości słoniowej czy drewna ${ }^{32}$. Sposób kształtowania partii brzucha postaci dworzanina, charakterystyczny jest zarówno dla rzeźb z XVII jak i XVIII w. ${ }^{33}$. Wśród eksponatów na berlińskiej wystawie Benin - Kings and Rituals. Court Arts from Nigeria, z 2008 r. znalazły się statuetki z kości słoniowej i liczne rzeźby mosiężne, datowane na wiek XVIII, o analogicznie ukształtowanych partiach włosów, oczu, brzucha, szat, biżuterii. Datowanie tych obiektów opierało się na badaniach materiałowych ${ }^{34}$.

\footnotetext{
${ }^{30}$ K. Curnow, Prestige..., s. 80.

31 Formy, jakie wykorzystywane były przez warsztat odlewników i rzeźbiarzy przenikały z jednego warsztatu do drugiego (D. Inneh, The Guilds Working for the Palace, [in:] Benin - Kings and Rituals, op. cit, s. 107).

32 B. Blackmun, Who are the Figures in Benin Art? Translations from Ivory to Bronze, [in:] Benin - Kings and Rituals, op. cit., s. 163. Badaczka zwróciła uwagę, iż wzory z kłów słoniowych i rzeźb z kości przenikały do dzieł odlewniczych tworzonych przez warsztat Igbesanmwan.

33 K. Curnow, op. cit., s. 80. Analogiczny sposób kształtowania brzucha był również charakterystyczny dla rzeźb z Ife, które oddziaływało na rzemieślników z Beninu (A.F.C. Ryder, A Reconsideration of the Ife-Benin Relationship, "The Journal of African History" 1965, Vol. 6, No. 1, s. 25-37). Relacje artystyczne pomiędzy tymi dwoma ośrodkami istniały już od około X-XI w. (D. Inneh, op. cit., s. 29).

$34 \mathrm{~W}$ artykule P. Junge'a przedstawione zostały metody datowania głów mosiężnych, pochodzących z ołtarzy przodków, z kolekcji Ethnologisches Museum w Berlinie (zob. P. Junge, Age Determination of Commemorative Heads. The Example of the Berlin Collection, [in:]
} 
W zbiorach Metropolitan Muzeum of Art w Nowym Jorku, a także w The Trustees of the National Museums Scotland w Edynburgu, oraz w kolekcji Sir W. Northrupa McMillana ${ }^{35}$ znajduje się kilka pełnopostaciowych statuetek kobiecych z kości słoniowej, wykazujących pewne podobieństwo stylistyczne do rzeźby toruńskiej, szczególnie w modelunku twarzy i włosów. Wszystkie rzeźby datowane są na wiek XVIII i mierza ponad $30 \mathrm{~cm}$. Natomiast do zbiorów Gelbard Collection of African Art ${ }^{36}$ należy figurka przedstawiająca postać mężczyzny o analogicznych skaryfikacjach w partii torsu, oraz na policzkach. Różnicą są skaryfikacje, także na czole (kilka nacięć w formie krótkich kresek), charakterystyczne dla oby. Podobieństwo istnieje też w modelunku kragłego brzucha, fryzurze i pozie postaci. Podobnie ukształtowano również ozdoby - bransolety i naszyjniki. Różnicę stanowi strój, który w przypadku rzeźby toruńskiej posiada remini-

Benin - Kings and Rituals, op. cit., s. 185-195). Głowy brązowe z artykułu Junge'go, najbliższe stylistyczne, pod względem ukształtowania nosa, oczu i rysów twarzy, to głowy o numerach IIIC07658, IIIC08527, IIIC08170, a także głowa IIIC12508. Głowa nr IIIC12508 ma podobnie ukształtowane usta i oczy, a także grubsze od pozostałych naszyjniki. Została ona zaliczona, według badań przytoczonych przez autora, prowadzonych przez Otto Wernera, na podstawie składu stopu bez zawartości cynku, do grupy najstarszych obiektów z kolekcji berlińskiej, podobnie jak głowa IIIC08527 i IIIC07658. Głowa IIIC08170 datowana na XV lub XVI w. Według badań prowadzonych w 2000 r. przez Franka Willetta i Edwarda V. Sayre'a, opierających się na dokładnym zbadaniu składu stopów, dla określenia czasu powstania głów berlińskich, badacze podzielili obiekty na sześć grup chronologicznych (P. Dark, Benin Bronze Heads: Styles and Chronology, [in:] African Images: Essays in African Iconology, ed. Daniel F. McCall, Edna G. Bay, New York 1975, s. 25-10). Głowa IIIC07658 i IIIC08527 zostały zaliczone do grupy drugiej, datowanej na okres od XV do połowy XVII w., a głowa IIIC12508 - od połowy XVII do początku XVIII w.. (P. Junge, op. cit., s. 186-187). W trakcie badań materiałowych metodą termoluminescencji, prowadzonych w 1993 r., przez Christiana Goedicke'a i Sabine, pozwoliły na ustalenie przybliżonej daty powstania odlewów dwóch głów: IIIC07658 wydatowana została na rok 1729, a IIIC08170 na 1859 r. Analizy materiałowe przesunęły datowania ustalone przez Philipa Darka, opierającego się głównie na typologii, który głowy (bez IIIC12508) datował na wiek XV (Ibidem, s. 186-187.). Powyższa analiza badań nad określeniem czasu powstania brązów benińskich, pozwala zobrazować, jak wielka była trwałość form, zarówno odlewniczych jak i rzeźbiarskich, i jak trudno jest jednoznacznie określić czas powstania.

35 Nr inw.: A 1985.633, A.1985.632. Katalog nr 177 i 178, [w:] Benin - Kings and Rituals, op. cit., s. 403.

36 S. Rodolitz, A. Bourgeois, Remnants of Ritual: Selections from the Gelbard Collection of African Art, New York 2003, s. 18, fig. 40. 
scencje portugalskie, natomiast statuetka amerykańska przedstawiona została w tradycyjnym stroju. Jest ona datowana na okres od XV do XVI w. ${ }^{37}$

Wielkość rzeźby i jej charakterystyczne ścięcie od spodu, może świadczyć, iż jest to fragment większego przedmiotu. Wgłębienie od spodu i przebarwienia kości u wylotu sugeruja, iż rzeźba stanowiła pierwotnie rękojeść sztyletu, noża lub przedmiotu kultowego. Toruńska statuetka z kości słoniowej wymaga wciąż jeszcze dalszych analiz, a także badań materiałowych, które pozwoliłyby na dokładne ustalenie jej pochodzenia oraz czasu powstania.

W kolekcji Aleksandra Wernera znajduje się również kilka rzeźb drewnianych z pierwszej połowy XX w. Jedną z nich jest figura żeńskiego bliźniaka ibeji, (nr inw: MUT 238/KW 3) (il. 2) ludu Joruba z Nigerii. Mierzy $28 \mathrm{~cm}$ wysokości i wykonana została w miękkim drewnie o czerwonawym kolorycie (prawdopodobnie iroko). W zagłębieniach znajduja się ślady po proszku drzewnym, którym nacierano lalkę, a w partii fryzury - indygo. Jest to typowy przykład formy kanonu rzeźbiarskiego z tego regionu Afryki.

W Królestwie Jorubów kult bliźniąt ibeji rozwiną się w połowie XVIII w., spowodowany dużą śmiertelnością wśród niemowląt oraz jednym z najwyższych na świecie wskaźników narodzin bliźniaczych ${ }^{38}$. Kanon ibeji narzucał twórcom ściśle określona formę ${ }^{39}$, narzuconą także przez ich funkcję użytkową ${ }^{40}$, dlatego też lalki z różnych regionów zamieszkiwanych

37 Ibidem.

38 P.P.S. Nylander, The Frequency of Twinning a Rural Community In Western Africa, „Annual of Human Genetics" 1969, Vol. 33, s. 41-44.

39 Każda lalka mierzy ok. 20-30 cm wysokości, charakteryzuje się proporcją 1:3, jej modelunek jest schematyczny i walcowaty. Przedstawione w zawsze w pozycji stojącej, w rozkroku, o nieproporcjonalnie krótkich nogach i rękach, bez wyraźnie zaznaczonych kolan i łokci, z uwydatnionymi cechami płciowymi postaci są statyczne. Ich cechą charakterystyczną są ręce ułożone łukowato wzdłuż ciała, charakterystyczne wysokie fryzury, uwydatnione głowy, ze schematycznie potraktowanymi twarzami o uwydatnionych oczach, ustach i nosach, z dużymi odstającymi uszami, w których często zamieszano ozdoby. Zob. M. Baka-Theis, Rz̨ȩ́by bliźniat ibedīi. Forma i styl wybranych regionów Królestwa Joruba (Nigeria), [w:] Kultury Afryki. W swiecie tradycji, praemian i znaczen | Cultures of Africa. In the world of traditions, changes and meanings, t. IV, red. A. Nadolska-Styczyńska, Toruń 2009, s. 133-143.

40 Ibeji nie tylko stawiano na domowych ołtarzykach, ale także noszono w chuście na brzuchu, tak samo jak żywe dzieci. Ibidem. 
przez Jorubów, różnią się miedzy sobą jedynie detalem (fryzury, modelunkiem twarzy, ukształtowaniem kończyn, strojem). Istnieje kilkadziesiąt regionalnych odmian tych rzeźb ${ }^{41}$.

Pochodząca prawdopodobnie z miasta Ogbomoso, jednego z głównych ośrodków rzeźbiarskich prowincji Ojo, rzeźba z kolekcji Wernera, odpowiada formom stosowanym w tym regionie. Przemawiaja za tym skaryfikacje twarzy, co w przypadku lalek z pierwszej połowy XX w., może mieć bezpośrednie odniesienie do miejsca pochodzenia ${ }^{42}$. W publikacji Ibeji. The Cult of Yoruba Twins, zamieszczono fotografię z 1980 r., wykonaną w mieście Ogbomoso w Ojo, przedstawiająca kobietę trzymającą w dłoniach dwie analogiczne figurki bliźniąt ibeji ${ }^{43}$.

Poza lekkimi przetarciami i ubytkiem w partii nosa, ibeji z Torunia jest dobrze zachowana. W zagłębieniach reliefu fryzury widoczne są pozostałości po indygo, a w partii rakk, dłoni, stóp i w pachwinach - proszku drzewnego, którym nacierano kultowe statuetki, co świadczyć może o tym, iż była ona użytkowana i jest autentyczną figurką kultowa. Dodatkowo w uszach przewiercono otwory, w których umiejscowione były ozdoby, o czym świadczą lekkie przetarcia.

W kolekcji uniwersyteckiej znalazły się także dwie lalki akuaba ludu Aszanti z Ghany, datowane na XX w. Kobiety, w celu zapewnienia sobie płodności, spokojnego porodu i zdrowia dla swoich przyszłych potomków, nosiły lalki przytroczone do pleców, podpowiadając w ten sposób bóstwom, iż chciałby urodzić piękne dziecko ${ }^{44}$.

41 Podział regionalny nie jest tożsamy ze współczesnym podziałem administracyjnym Nigerii, lecz z podziałem regionalnym Królestwa Joruba. Można wśród nich wyróżnić m.in. style regionu Ojo, Ijebu, Efon, Ekiti, Igbomina. Wyróżniono ponad 160 ich typów (F. Polo, J. David, Catalogue of the Ibeji. 2. Vols, Vol. 1: Zürich 2001, ss. 260; Vol. 2: Zürich 2005, ss. 295).

42 S. Johnson, The bistory of the Yorubas, Lagos 1921, s. 740, s. 21.

43 J. Pemberton III, Ere Ibeji: An Affirmation of Life in the Face of Death, [in:] G. Chemeche, Ibeji. The Cult of Yoruba Twins, Milan 2003, s. 37.

${ }^{44}$ Zob. M. Baka-Theis, „Lalecrka-córecrka” - lalki płodności Akua'ba ludu Aszanti (Ghana) i inspiracje, [w:] Ciało symboliczne. Ciato medyczne. Ciało estetyczne. Materiały z Konferencji Naukowej zorganizowanej przez Sekcję Dawną Koła Naukowego Studentów Historii Sztuki Uniwersytetu Lódzkiego, Łódź, 22-23.02.2008 r., Lódź 2008, s. 7-26. Lalki akuaba sa głów- 
Obie lalki sa przykładem kanonu akuaby ${ }^{45}$, który podobnie jak statuetki ibeji, charakteryzuje się ogólnie przyjętą formą przez twórców tego ludu. Lalki odznaczały się starannością wykonania i wykwintnością modelunku, ponieważ miały stanowić miejsce dla duszy przyszłego dziecka. Jak podkreśla ks. Jacek Pawlik, celowo estetyzowano rzeźby, tak aby spodobały się one przodkom bądź duchom ${ }^{46}$, dlatego artyści Aszanti starali się, aby akuaby odznaczały się szczególnym pięknem. Czarna lalka ze zbiorów uniwersyteckich (nr inw.: MUT 239/KW 4), il. 3 mierzy 39 cm wysokości, została dokładnie opracowana. Tył jej głowy zdobi płytki zgeometryzowany relief, który nawiązuje do aszanckiej symboliki adinkra ${ }^{47}$, stosowanej także w zdobieniu tkanin, ceramiki czy detalu architektonicznego. $\mathrm{Na}$ jej powierzchni zauważalne sa przetarcia, co sugeruje, że była stosowana w celach kultowych. Druga akaba, wykonana z jasnego drewna (nr inw.: MUT 240/ /KW 5) (il. 4), mierzy 30 cm wysokości, a jej opracowanie nie jest tak dokładne. Być może wykonana została na potrzeby rynku pamiątkarskiego. Nie mniej jednak, obie rzeźby, prezentuja jedną z najlepiej rozpoznawalnych i najczęściej powielanych form tradycyjnej sztuki afrykańskiej.

W zbiorach Muzeum Uniwersyteckiego w Toruniu znajduje się również maska chiwara, ludu Bamana z Mali. ${ }^{48}$ (nr inw.: MUT 236/KW 1) (il. 5). Mie-

nie płci żeńskiej. Ma to swoje korzenie w micie o dziecku Akui - kobiecie która nie mogła mieć dzieci. Miejscowy szaman zalecił jej żeby wykonanie lalki, którą miała opiekować się jak prawdziwym dzieckiem. Wkrótce Akua urodziła dziewczynę o niezwykłej urodzie (K. Antubam, Akuaba, [in:] Kofi Antubam, Ghana's heritage of Culture, Leipzig 1963, s. 163-164).

45 Typowa lalka akaba mierzy od $20-50 \mathrm{~cm}$. Jest to schematycznie ujęta postać z płaska, dyskowata głowa, o małych oczach, ustach i wyraźnie zarysowanych brwiach przechodzących w wąski nos, zarysowanych poniżej połowy wysokości dysku twarzy. Odwrocie dysku zwykle zdobione jest płytkim reliefem. Walcowaty trzon, połączony z dyskiem głowy, stanowi tułów, na 1/3 wysokości którego, zwykle umiejscowione są małe, stożkowate, schematycznie ujęte piersi, na wysokości których schematycznie potraktowane ręce, uformowane z krótkich walców lub stożków. Lalki współczesne są bardziej naturalistyczne i często przedstawiane sa z uformowanymi kończynami.

46 J.J. Pawlik, Rola sztuki w afrykeańskim kulcie przodków, [w:] Afryka na progu XXI wieku. T. 1. Kultura i spoteczeństwo, red. J.J. Pawlik, M. Szupejko, Warszawa 2009, s. 107-111.

47 P. Appiah, Akan Symbolism, "African Arts" 1979, Vol. 3, No. 1, s. 64-67.

48 D. Zahan, A.F. Roberts, The Two Worlds of Ciwara, "African Arts" 2000, Vol. 33, No. 2, s. 34-45, 90-91. 
rzy ona $125 \mathrm{~cm}$ wys., $10 \mathrm{~cm}$ szer., wykonana została z lekkiego drewna, w tzw. typie wertykalnym. Jest to rzeźba pochodzaca maski koszowej ${ }^{49}$, w formie stylizowanej, zgeometryzowanej postaci antylopy, wyrzeźbiona z jednego kawałka drewna, z wtórnym, niestarannie opracowanym, prawym rogiem. Maski te związane były z kultem ziemi i rolnictwem, oraz symbolizowały boga Faro ${ }^{50}$ i mitycznego ducha pracy. Przedstawiały zamieszkująca teren sawanny antylopę, której długie rogi symbolizowały proso i odnosiły się do obfitości i urodzaju.

Maski te powstawały w kilku wariantach i były charakterystyczne dla danego regionu zamieszkiwanego przez Bamanów. W regionie Bamako rzeźbiono naturalistyczne antylopy o formie horyzontalnej, natomiast typ o formie abstrakcyjnej (na którą składały się schematycznie ujęte postaci np. antylopy, mrównika i kameleona) pochodził z regionu Seguni ${ }^{51}$. W regionie Segu, skąd pochodzi rzeźba toruńska, tworzono maski horyzontalne. Według Dominique Zahan i Allena Roberta forma masek odpowiadała rodzajowi hodowanego na danym terenie zboża i innej roślinności ${ }^{52}$.

Mimo częściowego uszkodzenia (róg, ubytki w partii uszu), rzeźba ta jest autentyczna, stosowaną w kulcie chiwara maska, na co wskazują ślady po sznurkach, którymi przytwierdzano rzeźbę do kosza, uszkodzenia i przetarcia na zakończeniu oryginalnego rogu ${ }^{53}$. Miejscami widoczne sa ślady po pigmencie, szczególnie w partii pyska i grzbietu, maska była więc pierwotnie polichromowana. Mogła być też zdobiona elementami metalowymi, na co wskazują liczne wgłębienia, a także przewiercone ucho, w którym zawieszano kolczyki. Maska pochodzi zapewne z połowy XX w.

Do swojej kolekcji Aleksander Werner nabył także małą maskę, prawdopodobnie piersiowa, zbliżona stylistycznie do kregu stylu ludu Baule, za-

49 Zob. s. I. Hahner, M. Kecskési, L. Vajda, African masks. The Barbier-Mueller Collection, Munich-Berlin-London-New York 2007, s. 15.

50 S.R. Wooten, Antelope Headdresses and Champion Farmers. Negotiating Meaning and Identity through the Bamana Ciwara Complex, "African Arts" 2000, Vol. 33, No. 2, s. 20.

51 Bamana. The Art of Existence in Mali, ed. Jean-Paul Colleyn, New York 2001, s. 263.

52 D. Zahan, A.F. Roberts, op. cit., s. 34-45.

53 Jest to związane $\mathrm{z}$ faktem używania maski w czasie maskarad, gdzie uderza się rogami o ziemię. W rzeźbie toruńskiej, w zagłębieniach rogów znaleziono osad ziemny, a także liczne przetarcia i zarysowania faktury. 
mieszkującego Wybrzeże Kości Słoniowej (nr inw.: MUT/244/KW/9) (il. 6). Została ona wykonana z lekkiego, czernionego drewna, mierzy $18,5 \mathrm{~cm}$ wysokości i 12,5 cm szerokości. Przedstawia twarz kobiecą o delikatnych rysach, o miękkim modelunku.

Zakładając jej użytkowe a nie pamiątkarskie przeznaczenie, przyjęto, iż jest to tzw. maska paszportowa ${ }^{54}$. Miniaturowe maski były wykonywane przez wiele ludów z Wybrzeża Kości Słoniowej (Dan, We, Guro, Loma, Bete, Konor). Służyły m.in. jako osobisty przedmiot mężczyzn po inicjacji, który zawsze noszono przy sobie. Oznaczały przynależność do tajnych stowarzyszeń ${ }^{55}$ lub awans w ich hierarchii, legitymizowały obecność i prawo głosu w radach starszych. Gdy nie były używane, przechowywano je w światyniach lub składano na domowych ołtarzykach. Odzwierciedlały formę większych masek, według których były wykonywane. Baule wierzyli, że przedmioty ceremonialne zamieszkiwały duchy, dlatego nie wystawiano ich na widok publiczny. Nawet maski taneczne widziane były zawsze w ruchu $i$ to $z$ pewnej odległości, dlatego patrzenie na nie, nie stanowiło wielkiego zagrożenia. Susan Vogel, zwróciła uwagę na istotny aspekt neutralizowania oddziaływania rzeźb w kulturze Baule, poprzez zmianę ich kontekstu, funkcji, a przede wszystkim miniaturyzację. Maski portretowe, według Vogel, należą do grupy przedmiotów prywatnych, wykonywanych na użytek zamawiajaccego. Przechowywane były w workach lub pod przykryciem, ale wykonanie miniatury takiej maski pozwalało właścicielowi cieszyć się jej widokiem. Formy masek, na które nie można było spoglądać, przedstawiane jako element zdobniczy przedmiotu, traciły swoje pierwotne znaczenie ${ }^{56}$. Karen Wilkin pisała: „Kobieta, jak się okazuje, może bezpiecznie spoglądać na małą, miniaturową wersję świętych masek, ponieważ, zakładając, że nigdy nie widziała autentyku, nie uzna miniatury jako repliki potężnego wizerunku" 57 .

${ }^{54}$ Ch.B. Steiner, The Invisible Face: Mask, Ethnicity and the State in Côte d'Ivoire, "Museum Anthropology" 1992, Vol. 16, No. 3, s. 53-57.

55 Tajne związki sa to grupy i stowarzyszenia w Afryce oparte na religijnej i społecznej podstawie, do których dostęp poprzedzała inicjacja. Zob. S. Piłaszewicz, Stownik mitologii i religii Czarnej Afryki, Warszawa 1996, s. 186.

56 S. M. Vogel, Baule. African Art - Western Eyes, New Heaven-London 1997, ps. 312.

${ }^{57}$ K. Wilkin, The Art of the Baule people, "New Criterion" 1999, Vol. 17, No. 6, s. 36. 
Trudne do identyfikacji było miejsce powstania maski. Nie można bowiem jednoznacznie stwierdzić czy rzeczywiście jest to twór rzeźbiarzy Baule, choć maska utrzymana jest w tym stylu. Podobne tworzyły ludy z nimi sąsiadujące, jak Yaure ${ }^{58}$ czy Guro ${ }^{59}$, wykonujące rzeźby i maski o podobnym modelunku twarzy ${ }^{60}$. Za Baule przemawiaja charakterystyczne skaryfikacje na policzkach i czole maski z kolekcji Wernera. Są one analogiczne ze znanymi z kolekcji muzealnych rzeźbami tego ludu. Podobne skaryfikacje policzkowe odnaleźć można na fotografii kobiety Baule, z jej maską portretowa, wykonanej w 1972 r., zamieszczonej w publikacji Arnolda Rubina ${ }^{61}$. Rzeźbiarz uchwycił podobieństwo, poprzez nadanie masce indywidualnych cech charakterystycznych portretowanej. Ma to ogromne znaczenie w sztuce Baule. Artyści potrafili wydobyć decydujące aspekty osobowości, tworząc zwięzłą formę, która wymuszała porównanie z modelem. Philip Revenhill pisał: „Wykonane dzieło sztuki jest rozumiane jako oddziałujące na widza, jak w przypadku Baule, gdzie pomyślnie wykonana rzeźba jest porównywana z modelem" ${ }^{62}$. Jednocześnie można zauważyć idealizację i utrzymanie rzeźby w kanonie plastyki Baule. W katalogu kolekcji Barbier-Mueller znajduje się bliźniacza maska mblo $^{63}$. Formy obu „twarzy” przypominają maskę z Muzeum Uniwersyteckiego. Na czole zostały dodane podobne trzy pary skaryfikacji w formie krótkich, płaskich nacięć. Analogiczne jest ujęcie łuków brwiowych, nosa i ust, a szczególnie sposób kształtowania twarzy i miękki modelunek.

Mimo pewnych watpliwości, maska toruńska wydaje się być najbliższa rzeźbiarskim tradycjom Baule, także z uwagi miniaturyzację stosowana

58 I. Hahner, M. Kecskési, L. Vajda, African Masks. The Barbier-Mueller Collection, Munich-Berlin-London-New York, kat. 37, 38.

59 H. Himmelheber, Kunst und Künstler der Baule und Guro, [in:] H. Himmelheber, Negerkunst und Negerkïnstler, Braunschweig 1960, s. 198-234.

${ }^{60}$ Maski Yaure i Guro charakteryzuje wąski nos, łukowate brwi, przymknięte powieki i małe usta, często ze szpiczastymi zębami. Natomiast maski Baule, posiadają miększy modelunek, delikatniej ujęte rysy twarzy, mały, lekko zaokraglony podbródek i uchwycone sa jakby w „zamyśleniu”.

${ }^{61}$ A. Rubin, Marks of Civilisation: Artistic Transformation of the Human Body, Los Angeles 1995, s. 145.

${ }^{62}$ P. L. Ravenhill, Likeness and Nearness. The Intentionality of the Head in Baule Art, "African Arts", 2000, Vol. 33, No. 2, s. 63.

${ }^{63}$ I. Hahner, M. Kecskési, L. Vajda, op. cit., kat. 41. 
przez tą ludność. Jednak konieczne są dalsze badania nad tym, niewatpliwie interesującym obiektem.

Z południowo-zachodniej Etiopii pochodzi podgłówek ludu Kambatta, odznaczający się prostą formą, zdobiony delikatnym, zgeometryzowanym reliefem i noszący piętno użytkowania, co świadczy o jego autentyczności (nr inw: MUT/241/KW/6) (il. 7). Wykonany został z jednego kawałka drewna (typ grenadill afrikan), mierzy 19,5 cm wysokości i $21 \mathrm{~cm}$ szerokości, jest niezwykle cienki w partii trzonu. Podobny podgłówek ludu Kambatta znajduje się w kolekcji Muzeum Etnograficznego w Krakowie. Analogię odnajdujemy także w zbiorach Uniwersytetu Kalifornijskiego w Los Angeles ${ }^{64}$. Podgłówek toruński powstał prawdopodobnie w pierwszej połowie XX w., ponieważ tego typu forma nie występowała już po tym okresie.

Tykwy z akurum ${ }^{65}$ z kolekcji Aleksandra Wernera, pochodzą z Kenii i są wytworem ludu Turkana (nr inw.: MUT 243/KW 8; nr inw.: MUT 244/ $/ \mathrm{KW} / 9)$. Sa to dwie ponad cztredziestocentymetrowe, polerowane i pomalowane bordowo-czerwonym i czarnym pigmentem naturalnym, dwuczęściowe pojemniki wykonane z tykwy, obwiązane skórzanymi rzemieniami, ze skórzaną wylewką, służące do przechowywania mleka lub żywności. Mniejsze, wąskie, górne części tykwy, stanowiły zatyczkę i kubek jednocześnie. Skóra jest mocno zeschnięta, a miejscami widoczne są metalowe nity zszywające spękania oraz ślady działalności owadów. Pojemniki z tykwy można datować na ok. połowę XX w., z uwagi na analogię z datowanym na lata 30.-40. XX w. tykwami z artykułu Alana Donovana, Turkana Functional $\mathrm{Art}^{66}$. Jest to charakterystyczny dla tego ludu sprzęt, natomiast spotykane są podobne przedmioty wśród innych ludów zamieszkujących dzisiejszą Kenię. Niewatpliwie tykwy z kolekcji Wernera były użytkowane, za czym przemawia m.in. ich charakterystyczny, ostry zapach.

${ }^{64}$ William J. Dewey, Toshiko M. McCallum, Jerome Feldman, Henrietta Cosentino, R. G. Wilcox, Sleeping Beauties: African Headrests and Other Highlights from the Jerome L. Joss Collection at UCLA, 1993, s. 39, fig. 18.

${ }^{65}$ Akurum - kubek wykonany z górnej części z tykwy.

${ }^{66}$ A. Donovan, Turkana Functional Art, "African Arts" 1988, Vol. 21, No. 3., fig. 1, 2, 6. 
Zbiór rzeźby uzupełniaja, wstępnie rozpoznane, naczynia ceramiczne: trzy późnośredniowieczne lub nowożytne naczynia powstałe w Północnej części Afryki (nr inw. MUT 662/KW 137-664/KW 139) oraz dwa naczynia z I poł. XX w.: marokańska flaszka na wodę (nr inw.: MUT 661/KW 136) i nubijskie (MUT 665/KW 140) Nie opracowany jest zespół biżuterii, w którym pojedyncze obiekty mogą pochodzić z Afryki.

Afrykanika Aleksandra Wernera, choć stanowią niewielką część podarowanej Toruniowi kolekcji, w znaczący sposób uzupełnią zbiory Muzeum Uniwersyteckiego pod względem dydaktycznym i symbolicznie nawiązuja do bogatej kolekcji Uniwersytetu Stefana Batorego w Wilnie, którego Uniwersytet Toruński jest kontynuatorem.

\section{Bibliografia}

Antubam Kofi, Akuaba, [in:] Kofi Antubam, Ghana's heritage of Culture, Leipzig 1963 , s. $163-164$

Appiah Glover, Akan Symbolism, "African Arts" 1979, Vol. 3, No. 1, s. 64-67

Baka-Theis Małgorzata, „Laleczka-córeczka” - lalki ptodności Akua'ba ludu Aszanti (Ghana) i inspiracje, [w:] Ciato symboliczne. Ciato medyczne. Ciato estetyczne. Materiały z Konferencji Naukowej zorganizowanej przez Sekcję Dawna Koła Naukowego Studentów Historii Sztuki Uniwersytetu Lódzkiego, Łódź, 22-23.02.2008 r., Lódź 2008, s. 7-26.

Baka-Theis Małgorzata, Rzę́́by bliźniat ibedìi. Forma i styl uybranych regionón Królestwa Joruba (Nigeria), [w:] Kultury Afryki. W swiecie tradycij, przemian i znaczeń | |Cultures of Africa. In the world of traditions, changes and meanings, t. IV, red. Anna Nadolska-Styczyńska, Torun 2009, s. 133-143

Bamana. The Art of Existence in Mali, ed. Jean-Paul Colleyn, New York 2001.

Ben-Amos Paula, Men and Animals in Benin Art, „Man” 1976, Vol. 11, s. 243-252

Ben-Amos Girshick Paula, The Symbolism of Ancestral Altar in Benin, [in:] Benin - Kings and Rituals. Court Arts from Nigeria, ed. Barbara Plankensteiner, Wien-Berlin-Paris-Chicago 2007, s. 151-159

Blackmun Barbara W., From Trader to Priest in Two Hundred Years: The Transformation of a Foreign Figure on Benin Ivories, "Art Journal” 1988, s. 128-138

Blackmun Barbara W., Who are the Figures in Benin Art? Translations from Ivory to Bronze, [in:] Benin - Kings and Rituals. Court Arts from Nigeria, ed. Barbara Plankensteiner, Wien-Berlin-Paris-Chicago 2007, s. 160-169 
Blier Suzanne P., Imaging otherness in ivory: African portrayals of the Portuguese ca. 1492, "Art Bulletin" 1993, Vol. 75, No. 3, s. 375-396

Bohusz-Szyszko Marian, Wieliczko i jego Centaur Gallery, „Tydzień Polski” 1974, nr 37 , s. 4

Borkowski Andrzej M., Zastony i czeluście Aleksandra Wernera, „Tydzień Polski”, 25 X 1995, nr 42, s. 12 [przedruk w: Sztuka polska w Wielkiej Brytanii w latach 1940-2000. Antologia, wybrał, przygotował do druku i wstępem opatrzył M. A. Supruniuk, Torún 2006, s. 314-316]

Curnow Kathy, Prestige and the Gentleman. Benin Men's Ideal, "Art Journal" 1997, Vol. 56, No. 2, s. 75-81

Dark Philip, Benin Bronze Heads: Styles and Chronology, [in:] African Images: Essays in African Iconology, ed. Daniel F. McCall, Edna G. Bay, New York 1975, s. 25-103

Dewey William J., McCallum Toshiko M., Feldman Jerome, Cosentino Henrietta, Wilcox R.G., Sleeping Beauties: African Headrests and Other Highlights from the Jerome L. Joss Collection at UCLA, Los Angeles 1993

Donovan Alan, Turk.ana Functional Art, "African Arts" 1988, Vol. 21, No. 3, s. 44-47

Głuszek Inga, Kozłowska Ewelina, Majoch Sławomir, Olszta-Bloch Magdalena, Ancient pottery and glass from the collection of the University Museum in Torun $\mid C_{e-}$ ramika i sqketo antyczne w zbiorach Muzeum Uniwersyteckiego w Toruniu, (catalogues of the collection from University Museum in Torun | Poland | Katalogi zbiorów Muzeum Uniwersyteckiego w Toruniu, vol. 2, Toruń 2013

Himmelheber Hans, Kunst und Künstlerder Baule und Guro, [in:] Hans Himmelheber, Negerkunst und Negerkïnstlerder, Braunschwieg 1960, s. 198-234

Hołubowicz Włodzimierz, Mumje egipskie w Wilnie, Wilno 1933

Hołubowicz Włodzimierz, Pię́ lat pracy terenowej Muzeum Archeologicznego Uniwersytetu Stefana Batorego w Wilnie (1933-1937), „Rocznik Archeologiczny” 1937, t. 1 , s. $83-90$

Inneh Daniel, The Guilds Working for the Palace, [in:] Benin - Kings and Rituals. Court Arts from Nigeria, ed. Barbara Plankensteiner, Wien-Berlin-Paris-Chicago 2007, s. 103-117

Johnson Samuel, The History of the Yorubas, Lagos 1921

Junge Peter, Age Determination of Commemorative Heads. The Example of the Berlin Collection, [in:] Benin - Kings and Rituals. Court Arts from Nigeria, ed. Barbara Plankensteiner, Wien-Berlin-Paris-Chicago 2007, s. 185-195

Majoch Sławomir, Fascynujaca kolekicja. Dwaj oksfordzcy naukowy w torunskim Muzeum Uniwersyteckim, „Głos Uczelni” 2005, nr 2, s. 25

Majoch Sławomir, Tray tony dziet sztuki, „Głos Uczelni” 2004, nr 9, s. 16

Nevadomsky Joseph, Inneh Daniel E., Kingship Succession Rituals in Benin. 1: Becoming a Crown Prince, "African Arts" 1983, Vol. 17, No. 1, s. 51 
Okpewho Isidore, Principles of Traditional African Art, "The Journal of Aesthetics and Art Criticism" 1977, Vol. 35, No. 3, s. 304-305

Olszewski Wojciech, Założenia Muzeum Etnograficznego pray Uniwersytecie Stefana Batorego i ich rozwinięcie w pracach Marii Znamierowskiej-Prüfferowej, [w:] Prayysz̨ość etnologii polskiej w jej teraźniejszości, red. Z. Jasiewicz, T. Karwicka, Poznań 2001, s. 79-84

Pasztory Esther, Hieratic Composition in west African Art, "Art Bulletin" 1970, Vol. 52, No. 3, s. 299-306

Pawlik Jacek J., Rola særtuki w afrykańskim kulcie proodków, [w:] Afryka na progu XXI wieku. T. 1. Kultura i społeczeństwo, red. J.J. Pawlik, M. Szupejko, Warszawa 2009, s. $107-111$

Pemberton John III, Ere Ibeji: An Affirmation of Life in the Face of Death, [in:] George Chemeche, Ibeji. The Cult of Yoruba Twins, Milan 2003, s. 31-49

Pilaszewicz Stanisław, Stownik mitologii i religii Czarnej Afryki, Warszawa 1996.

Polo Fausto, David Jean, Catalogue of the Ibeji, 2 Vols, Zürich 2001.

Prüffer Jan, Muzeum Prayrodnicze Uniwersytetu Stefana Batorego w Wilnie, Wilno 1932 [nadbitka z: „Alma Mater Vilnensis” 1932, nr 10]

Ravenhill Philip L., Likeness and Nearness. The Intentionality of the Head in Baule Art, "African Arts" 2000, Vol. 33, No. 2, s. 60-72, 92

Rodolitz Scott, Bourgeois Arthur, Remnants of Ritual: Selection from the Gelbard Collection of African Art, New York 2003.

Rubin Arnold, Marks of Civilisation: Artistic Transformation of the Human Body, Los Angeles 1995

Ryder Allan F.C., A Reconsideration of the Ife-Benin Relationship, "The Journal of African History" 1965, Vol. 6, No. 1, s. 25-37

Sienkiewicz Jan Wiktor, Polskie galerie sætuki w Londynie w drugiej połowie XX wieku, Lublin-Londyn 2003

Sienkiewicz Jan Wiktor, Artysta piekna i nie tylko w sžkto zakletego. Aleksander Werner (1920-2011), „Archiwum Emigracji”, 2011, z. 1-2, s. 394-395.

Steiner Christopher B., The Invisible Face: Mask, Ethnicity and the State in Côte d'Ivoire, "Museum Anthropology" 1992, Vol. 16, No. 3, s. 53-57

Topolska Maria Barbara, Werner Aleksander, [w:] Encyklopedia polskiej emigracji i Polonii, red. K. Dopierała, t. 5: S-Ż, Toruń 2005, s. 232-233

Vogel Susan M., Baule. African Art - Western Eyes, New Heaven-London 1997, ss. 313

Wilkin Karen, The Art of the Baule people, "New Criterion" 1999, Vol. 17, No. 6, s. 32

Wooten Stephen R., Antelope Headdresses and Champion Farmers. Negotiating Meaning and Identity through the Bamana Ciwara Complex, "African Arts" 2000, Vol. 33, No. 2, s. 18-22, 89-90 
Zahan Dominiquw, Roberts Blen F., The Two Worlds of Ciwara, „African Arts” 2000, vol. 33, No. 2, s. 34-35, 90-91 il.

Znamierowska-Prüfferowa Maria, Mųeum Etnograficzne Uniwersytetu Stefana Batorego w Wilnie i jego praysz̨łość, Lwów-Wilno 1932 [nadbitka z: „Kwartalnik Etnograficzny Lud", 1932, Serja 2, t. 11]

\section{Summary}

\section{African artifacts from the collection of Aleksander Werener possessed by the University Museum Torun}

Article presents African collection donated by Alexander Werner (1920-2011), polish painter, sculptor and graphic, to Nicolaus Copernicus University in 2004. Werner lived in London since the end of II World War, when he created the rest of his life. All inheritance of the artist is University Museum in Torun. The introduction outlines the memoir of the artist.

The second part of the text is characteristic batch of African objects. The collection includes: sculpture of ivory from Kingdom of Benin (Fig. 1); wood and small figure Ibeji, "image of twins", form the Yoruba people of Nigeria from the Ivory Coast; (fig. 2); two dolls Akua'ba - wooden ritual fertility dolls from Ghana of Ashanti people (Fig. 3-4); the Antelope headdress Mask "Chi-wara" of thr Bamana people of Mali (Fig. 5); miniature "Passport Mask" whitch is a small portrait human face of Baule People (Fig. 6); paintedgourds Turkana Tribe of Norden Kenya, headrest Kambatta people of Ethiopia (Fig. 7) as well as five of pottery from North Africa. 


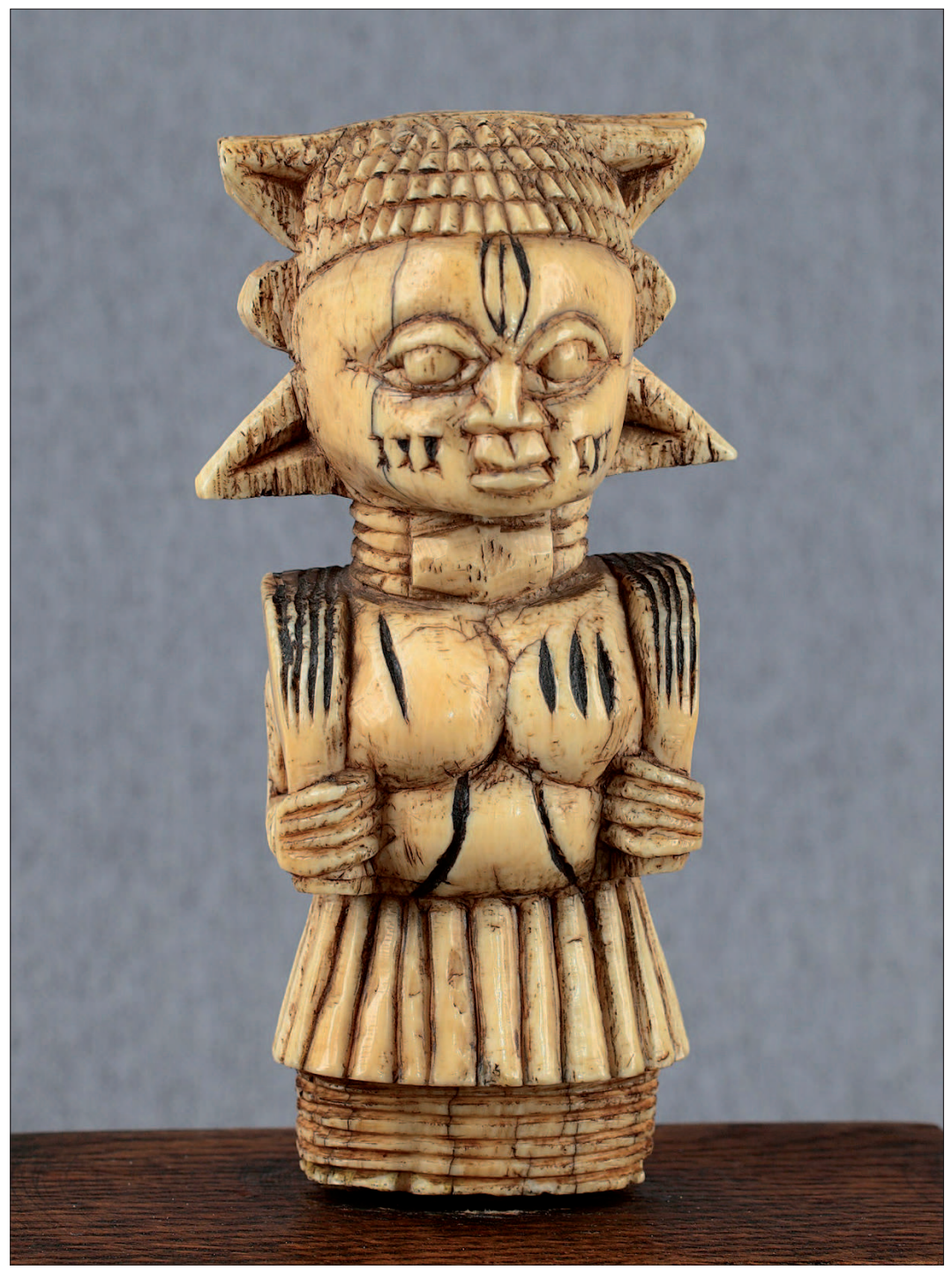

Il. 1. Urzędnik, lud Bini (Edo), Królestwo Beninu, Nigeria, XVIII w.; kość słoniowa, Muzeum Uniwersyteckie w Toruniu, nr inw.: MUT 237/KW 2. Fot. S. Majoch 


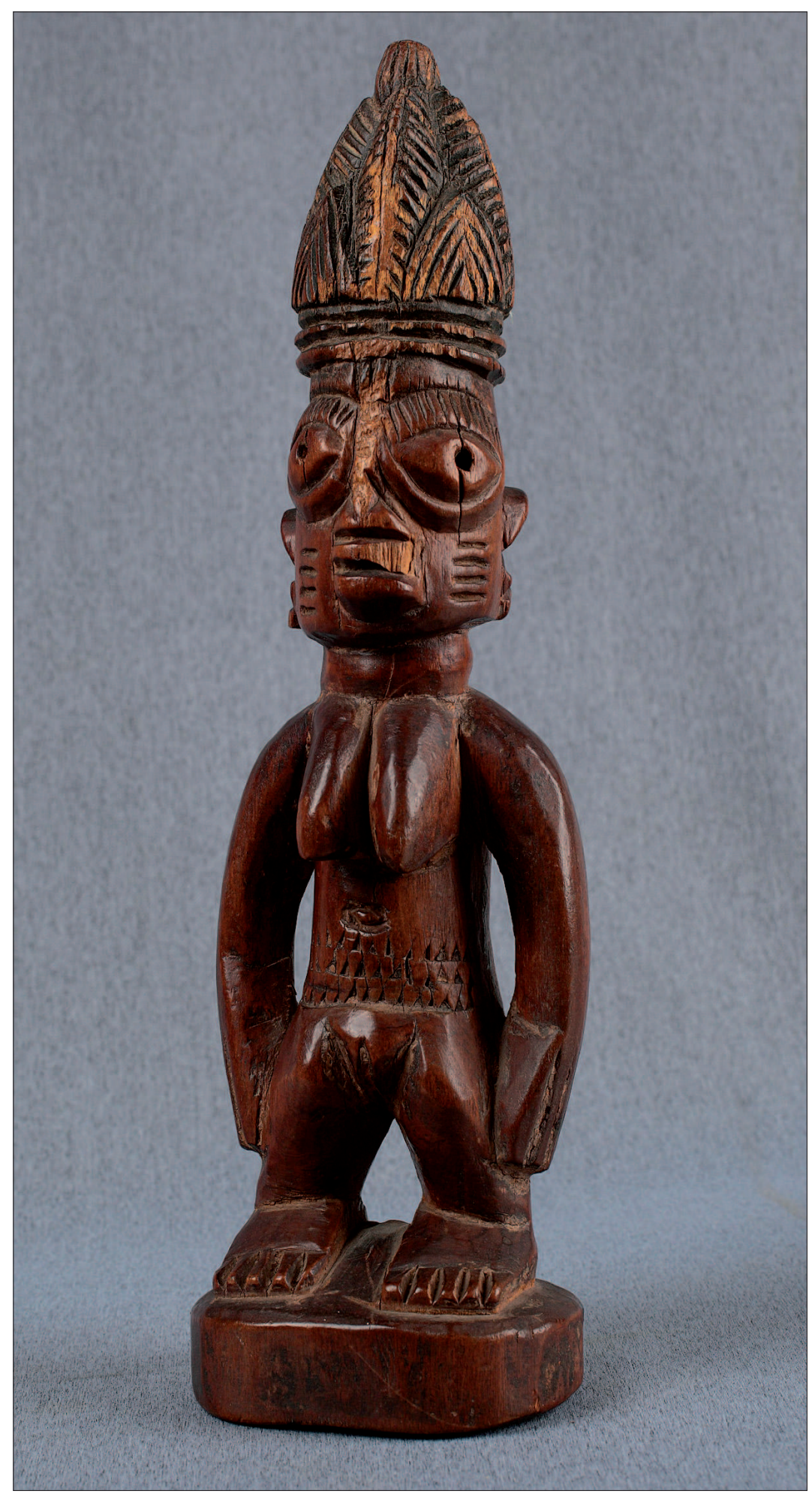

Il. 2. Ibeji, lud Joruba, region Ogbomoso, Ojo, Nigeria; poł. XX w.; drew -no nacierane pyłem drzewnym, czernione; Muzeum Uniwersyteckie w Toruniu, nr inw.: MUT 238/KW 3. Fot. S. Majoch 


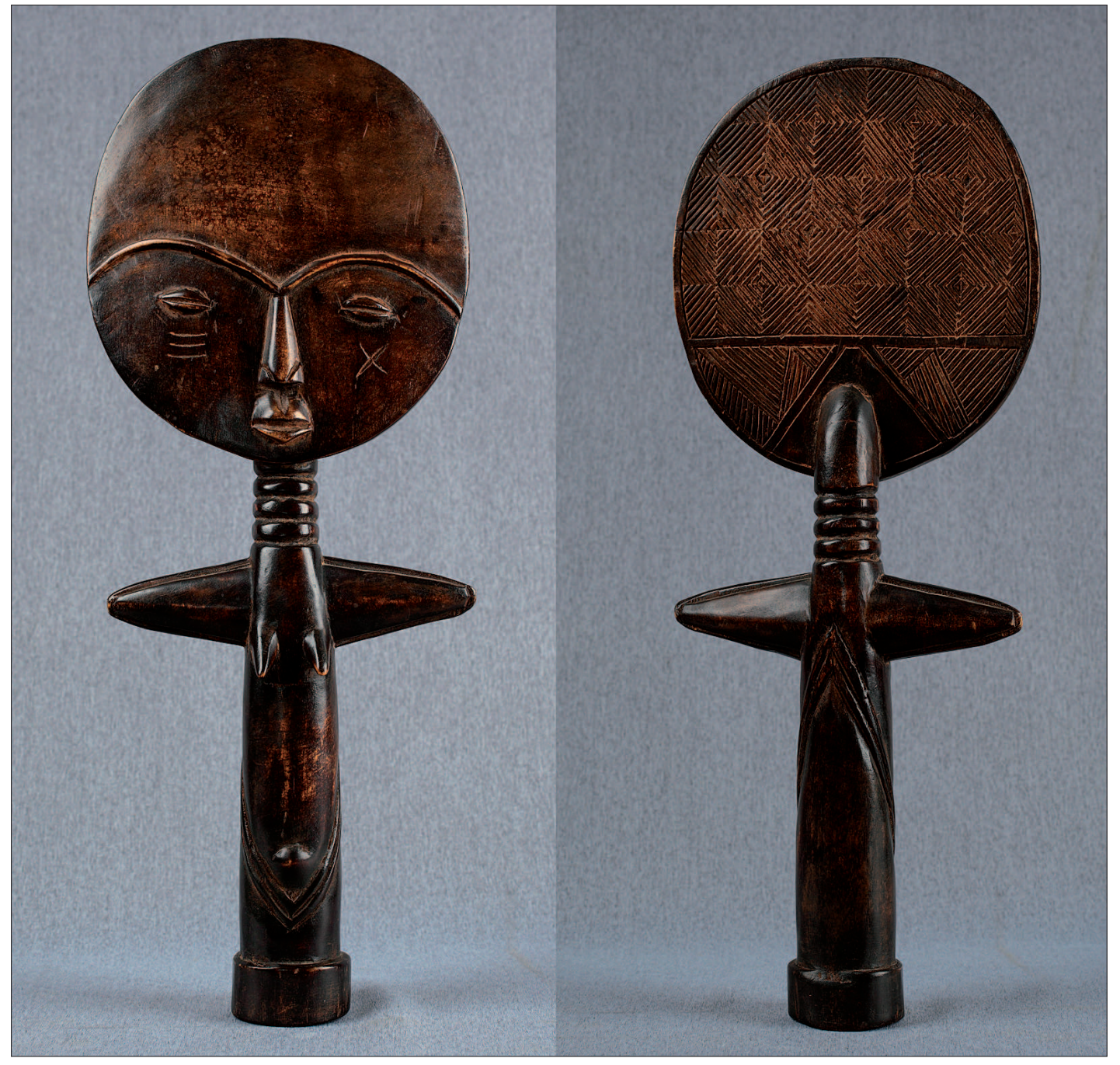

Il. 3. Akuaba, lud Aszanti, Ghana; 1 poł. XX w.; drewno czernione, Muzeum Uniwersyteckie w Toruniu, nr inw.: MUT 239/KW 4. Fot. S. Majoch 


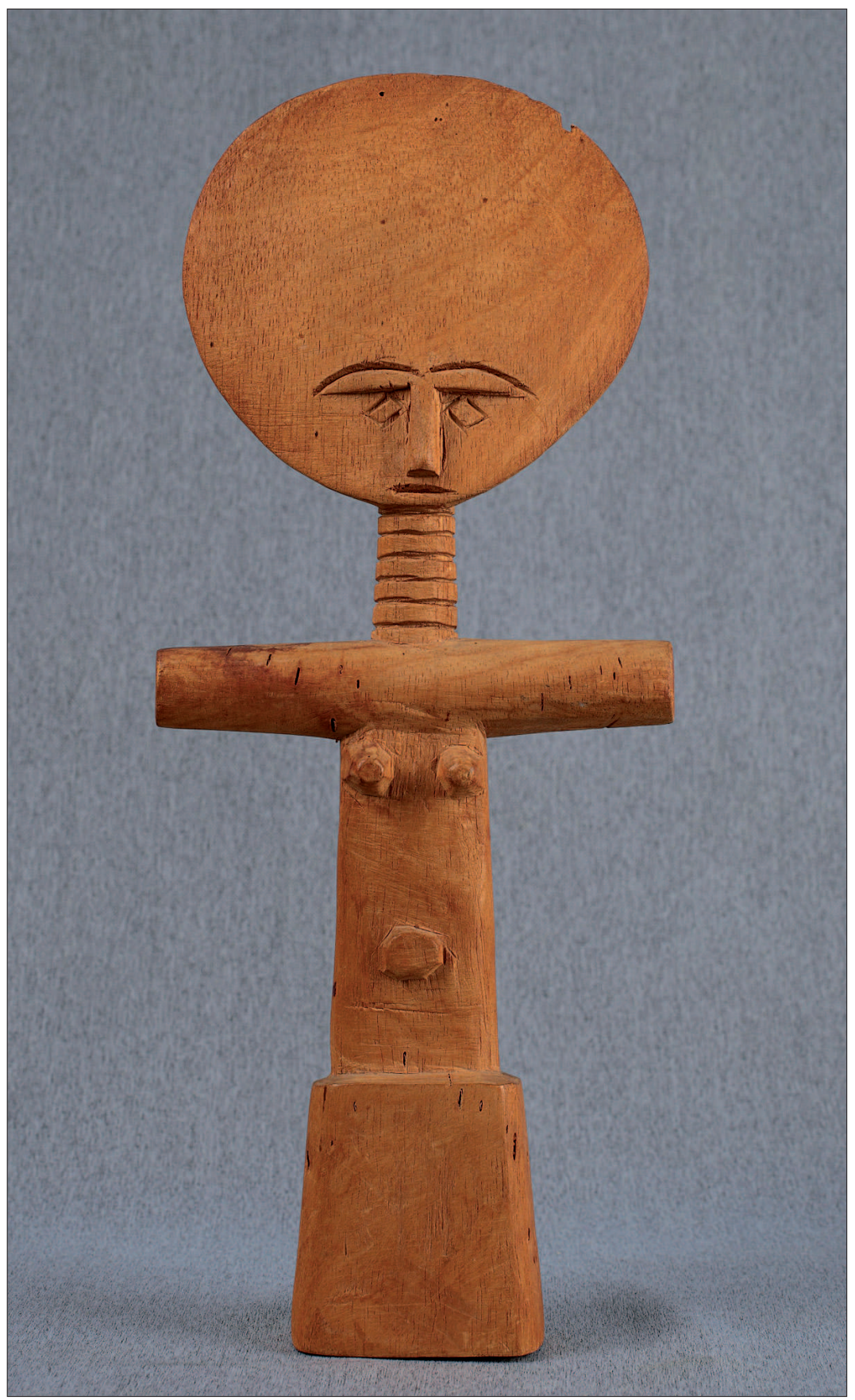

Il. 4. Akuaba, lud Aszanti; poł. XX w.; drewno, Muzeum Uniwersyteckie w Toruniu, nr inw.: MUT 240/KW 5. Fot. S. Majoch 


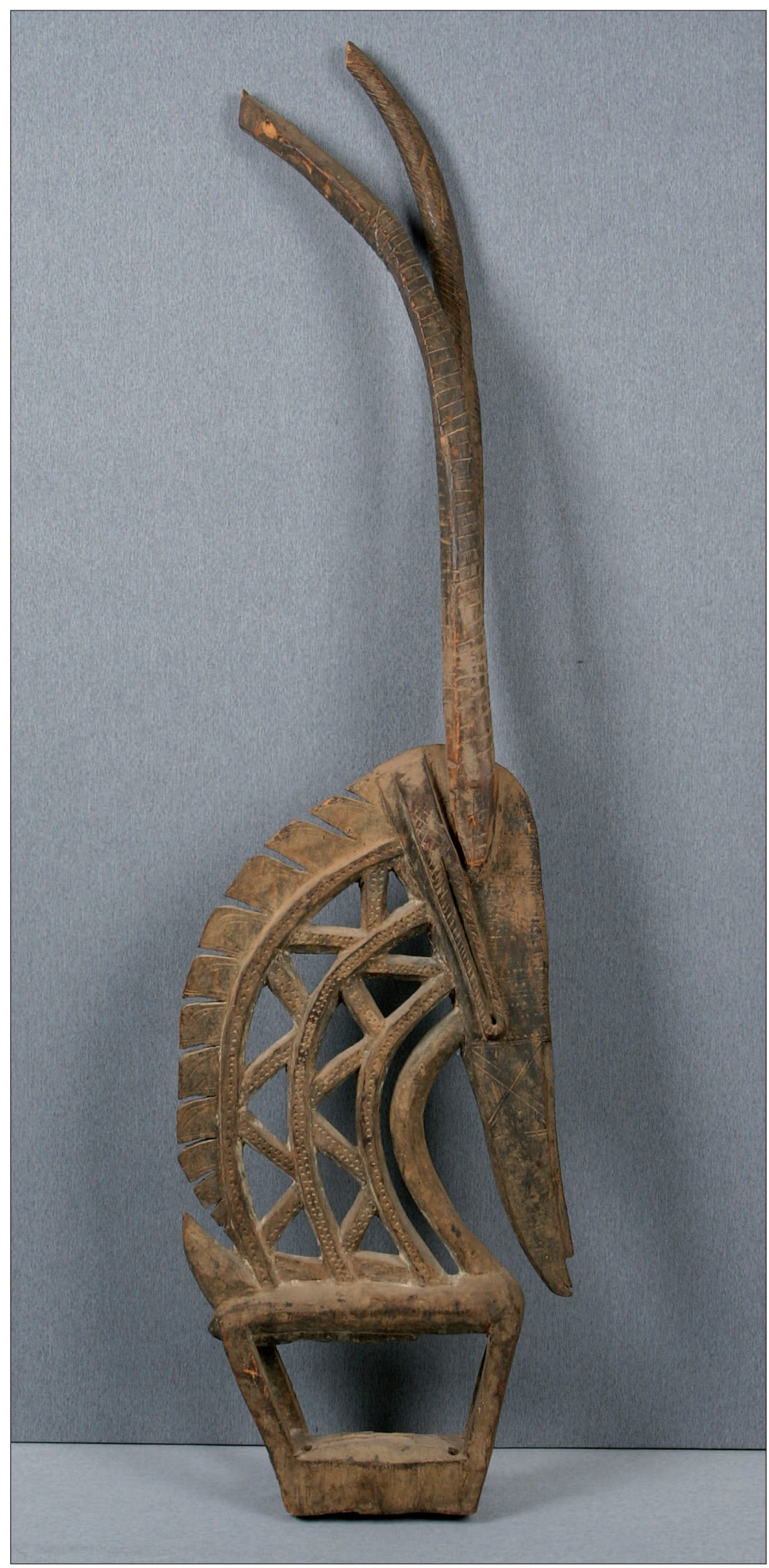

Il. 5. Maska kapeluszowa chiwara, lud Bamana, Mali, poł. XX w.; Muzeum Uniwersyteckie w Toruniu, nr inw:: MUT 236/KW 1. Fot. Piotr Kurek 


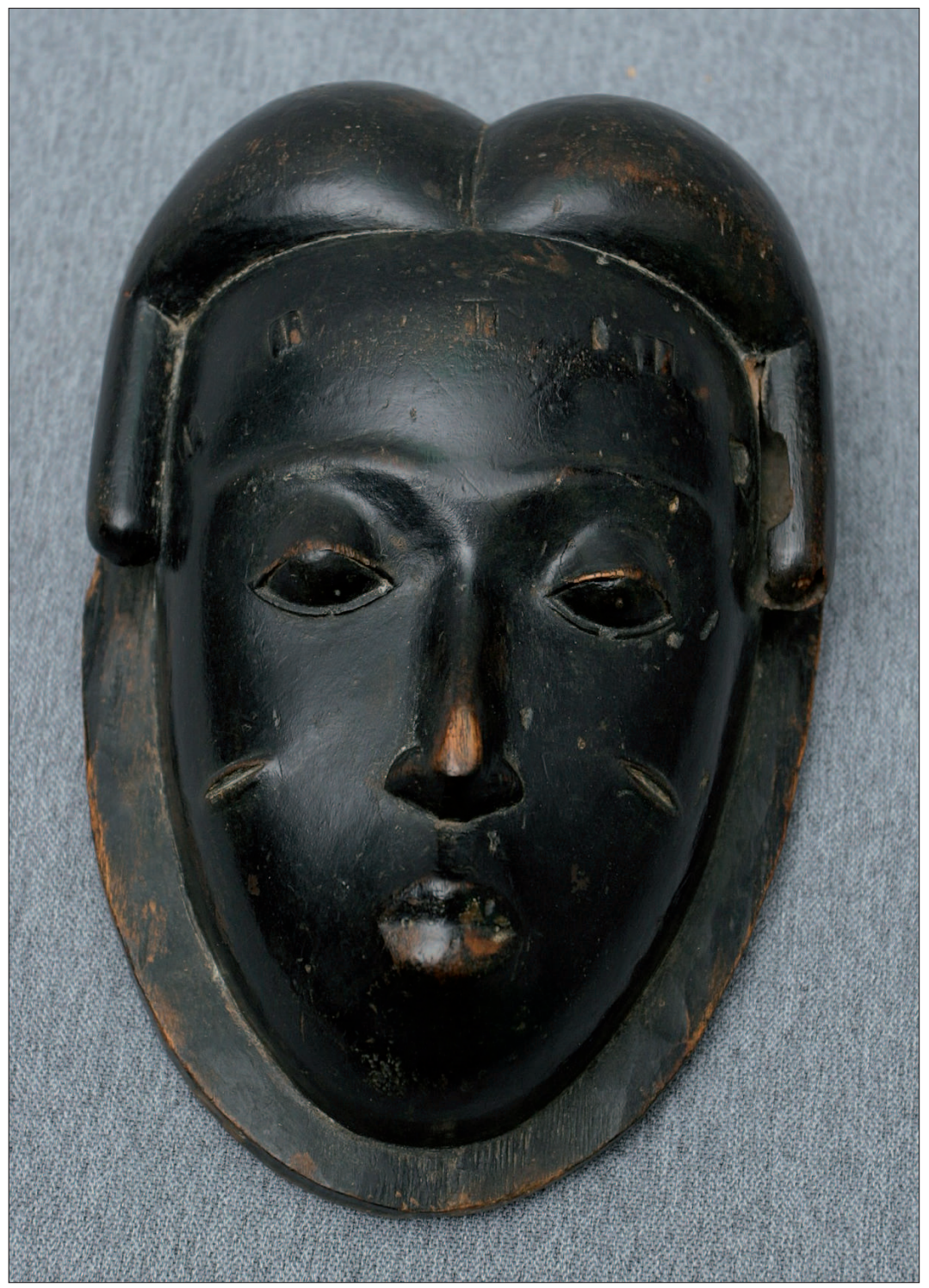

Il. 6. Maska miniaturowa, lud Baule, Wybrzeże Kości Słoniowej, poł. XX w.; drewno, Muzeum Uniwersyteckie w Toruniu, nr inw.: MUT 243/KW 9. Fot. S. Majoch 


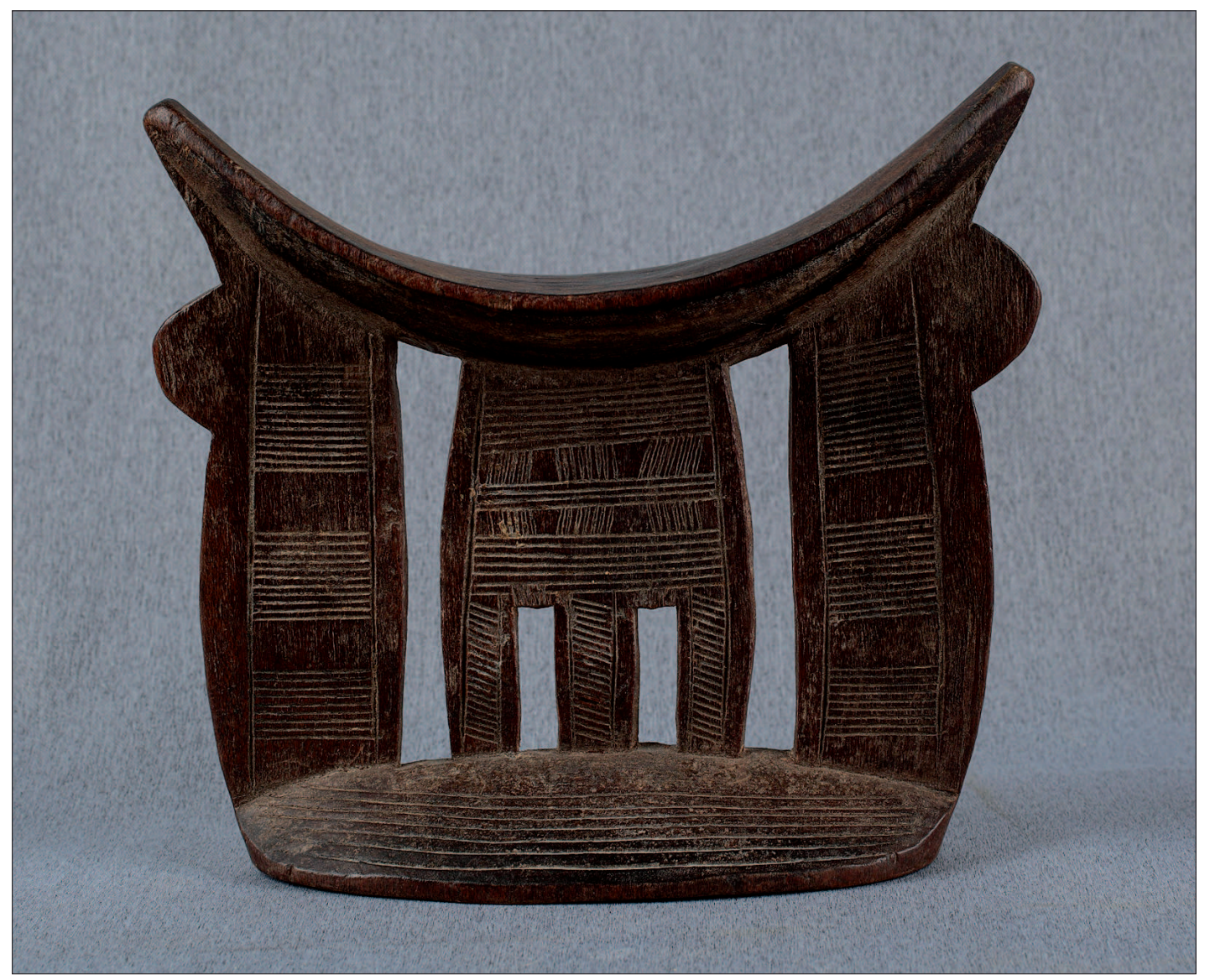

Il. 7. Podgłówek, lud Kambatta, Etiopia, 1 poł. XX w.; drewno, Muzeum Uniwersyteckie w Toruniu, nr inw.: MUT 241/KW 6. Fot. S. Majoch 